\title{
A multi-criteria decision model for the introduction of electric storage multiple units on the partially electrified Gdynia-Hel railway
}

\author{
Wielokryterialny model decyzyjny wprowadzenia elektrycznych \\ zasobnikowych zespołów trakcyjnych na częściowo zelektryfikowanej linii \\ Gdynia - Hel
}

\begin{abstract}
In this article, a multi-criteria study of the use of independently powered electric multiple units on the partially electrified Gdynia Gtówna - Hel railway was carried out. The use of (currently used) diesel and, as an alternative, electric and electric multiple units with an electric energy storage was considered. The analysis was carried out on the basis of three criteria for assessing the route service options, i.e. environmental, economic, operational and economic investment criteria. A multi-criteria decision model was developed for the analysis and a comparative analysis of the considered options for servicing the Gdynia Gtówna - Hel route was carried out. As part of the environmental criterion, it was found that the most environmentally friendly is the use of storage units. As part of the operational economic criterion, it was shown that the storage units have the lowest operating costs. The analysis, as part of the investment cost criterion, showed that the lowest investment costs are characteristic of route operation with the use of combustion units. The highest investment costs are related to the route operation by classic electric units, which is associated with the complete electrification of the line.
\end{abstract}

Przeprowadzono wielokryterialne studium zastosowania zasobnikowych zespolów trakcyjnych na częściowo zelektryfikowanej linii Gdynia Główna - Hel. Rozpatrzono zastosowanie używanych obecnie spalinowych oraz jako alternatywe, elektrycznych i elektrycznych zespotów trakcyjnych z zasobnikiem (magazynem) energii elektrycznej. Analize przeprowadzono $w$ oparciu o trzy kryteria oceny wariantów obshugi trasy, tj. kryterium środowiskowe, ekonomiczne eksploatacyjne oraz ekonomiczne inwestycyjne. Do analizy opracowano wielokryterialny model decyzyjny i przeprowadzono analizę porównawcza rozpatrywanych wariantów obstugi trasy Gdynia Gtówna - Hel. W ramach kryterium środowiskowego stwierdzono, iż najprzyjaźniejszym dla środowiska naturalnego jest zastosowanie zasobnikowych zespołów trakcyjnych. W ramach kryterium ekonomicznego eksploatacyjnego wykazano, że najniższymi kosztami eksploatacji charakteryzuja sie pojazdy zasobnikowe. Analiza $w$ ramach kryterium kosztu inwestycji wykazata, że najniższymi kosztami inwestycji cechuje sie obstuga trasy przy zastosowaniu zespołów spalinowych. Najwyższe koszty inwestycji zwiqzane sq z obstuga trasy przez klasyczne zespoły elektryczne, co wiqże się z calkowita elektryfikacja linii.

\section{INTRODUCTION}

According to the data provided by the Polish Central Statistical Office in 2019, the total length of railway lines in use in Poland is $19,325 \mathrm{~km}$. The length of electrified lines is $11,894 \mathrm{~km}$, which is nearly $62 \%$ of the total length of Polish railway lines. The rest of the lines are non-electrified. The nonelectrified lines in use in Poland are currently operated only by diesel traction vehicles. The use of these vehicles does not require advanced railway infrastructure, however, their operation adversely affects

\section{WSTĘP}

Zgodnie $\mathrm{z}$ danymi przedstawionymi przez Główny Urząd Statystyczny w 2019 r. łączna długość eksploatowanych w Polsce linii kolejowych wynosiła $19325 \mathrm{~km}$. Długość linii zelektryfikowanych wynosi $11894 \mathrm{~km}$, co stanowi blisko 62\% łącznej długości polskich linii kolejowych. Pozostała część linii jest niezelektryfikowana. Eksploatowane w Polsce niezelektryfikowane linie obecnie obsługiwane są wyłącznie przez spalinowe pojazdy trakcyjne. Użytkowanie tych pojazdów nie wymaga zaawansowanej infra- 
the local natural environment as a result of the emission of harmful substances in the process of fuel combustion. An alternative to the costly electrification of lines and the use of diesel traction vehicles, which is harmful to the local environment, may be the operation of lines with the use of storage traction vehicles. Their introduction into traffic does not require the construction of a traction network, which is characterized not only by high construction costs but also by the disturbance of the local landscape.

Storage electric multiple units - IPEMU (Independently Powered Electrical Multiple-Unit) are more and more widely used by developed European countries as an alternative to DMU (Diesel MultipleUnit) as well as electrification and use of classic electric units EMU (Electrical Multiple Units).

The specific railway Gdynia Główna - Hel was considered for the first national use of IPEMU, which is mainly single-track and non-electrified, and at the same time is characterized by a very high load in the summer season related to tourist traffic on the Hel peninsular. This railway consists of two sections. The first is the two-track electrified section Gdynia Główna - Reda, which is a part of line 202 connecting the Gdańsk Główny station with the Stargard station. The second single-track section covers the completely non-electrified line 213 Reda - Hel. This line runs through the Hel peninsula, which is fully protected by the natural environment under the Natura 2000 program [1]. These aspects lead to the consideration of introducing modern multiple units with energy storage in the form of batteries or accumulators with supercapacitors on this line.

Based on the results of the selection of the energy storage for electric multiple units presented in [11], it is advisable to analyze all aspects of the possible introduction of storage electric multiple units on a partially electrified line in one of the most attractive tourist regions of the Polish coast - the Hel peninsula.

The comparative analysis of the options for the operation of the partially electrified Gdynia Główna - Hel route was carried out on the basis of a multi-criteria decision model including environmental, economic, operational and investment criteria.

\section{BASIS OF THE DECISION MODEL - EVALUATION CRITERIA}

\subsection{Environmental criterion}

The environmental criterion for assessing possible variants of the Gdynia Główna - Hel route is a non-negligible criterion in the context of the nonelectrified line 213 running through the Hel peninsula. The modernization of railway line 213 should not disturb the landscape aesthetics of the Hel peninsula, which may occur in the case of the electrification of this line. Equally important as the landscape values is the noise emitted by the traction vehicle. struktury kolejowej, jednakże ich eksploatacja wpływa negatywnie na lokalne środowisko naturalne w wyniku emisji substancji szkodliwych $\mathrm{w}$ procesie spalania paliwa. Alternatywą dla kosztownej elektryfikacji linii oraz szkodliwego dla lokalnego środowiska naturalnego wykorzystania spalinowych pojazdów trakcyjnych może być obsługa linii przy wykorzystaniu zasobnikowych pojazdów trakcyjnych. Ich wprowadzenie do ruchu nie wymaga budowy sieci trakcyjnej, która charakteryzuje się nie tylko wysokimi kosztami budowy, ale również zaburzeniem miejscowego krajobrazu.

Niezależnie zasobnikowe elektryczne zespoły trakcyjne - z.e.z.t. (ang. Independly Powered Electrical Multiple-Unit) są coraz szerzej stosowane przez rozwinięte kraje europejskie, jako alternatywa dla zespołów spalinowych (ang. Diesel MultipleUnit) oraz elektryfikacji i używania klasycznych zespołów elektrycznych e.z.t. (ang. Electrical Multiple Units).

Do pierwszego krajowego zastosowania z.e.z.t. rozpatrzono specyficzną trasę Gdynia Główna - Hel, która jest głównie jednotorowa i niezelektryfikowana, a jednocześnie charakteryzuje się bardzo wysokim obciążeniem w sezonie letnim związanym z ruchem turystycznym na Mierzei Helskiej. Trasa ta składa się z dwóch odcinków. Pierwszym z nich jest odcinek dwutorowy zelektryfikowany Gdynia Główna - Reda, stanowiący fragment linii 202 łączącej stację Gdańsk Główny ze stacją Stargard. Drugi odcinek jednotorowy obejmuje w całości niezelektryfikowaną linię 213 Reda - Hel. Linia ta przebiega przez Półwysep Helski, który w całości objęty jest ochroną środowiska naturalnego $\mathrm{w}$ ramach programu Natura 2000 [1]. Aspekty te skłaniają do rozważenia wprowadzenia na tej linii elektrycznych nowoczesnych zespołów trakcyjnych z zasobnikiem energii $\mathrm{w}$ postaci akumulatorów lub akumulatorów z superkondensatorami.

Bazując na wynikach doboru zasobnika energii do elektrycznego zespołu trakcyjnego przedstawionych $\mathrm{w}$ [11], celowe jest przeanalizowanie wszystkich aspektów ewentualnego wprowadzenia zasobnikowych elektrycznych zespołów trakcyjnych na częściowo zelektryfikowanej linii w jednym $\mathrm{z}$ najbardziej atrakcyjnych turystycznie rejonów polskiego wybrzeża - Mierzei Helskiej.

Analizę porównawczą wariantów obsługi częściowo zelektryfikowanej trasy Gdynia Główna - Hel wykonano w oparciu o wielokryterialny model decyzyjny obejmujący kryterium środowiskowe, kryteria ekonomiczne eksploatacyjne oraz inwestycyjne.

\section{PODSTAWY MODELU DECYZYJNEGO - KRYTERIA OCENY}

\subsection{Kryterium środowiskowe}

Srodowiskowe kryterium oceny możliwych wariantów obsługi trasy Gdynia Główna - Hel jest 
The environmental criterion for assessing the railway service options also applies to the emission of $\mathrm{CO} 2$ (carbon dioxide) and other harmful substances into the atmosphere. A vehicle with an internal combustion engine emits harmful substances into the atmosphere at the place of its use, which is a significant disadvantage in the context of the area protected by the Natura 2000 program. In Poland, where currently more than $80 \%$ of electricity is produced by burning coal, emission of harmful substances as a result of energy production used to power electric vehicles is $29 \%$ lower than the emissions resulting from the operation of vehicles powered by internal combustion engines [1].

\subsection{Operating cost criterion}

There are five different maintenance levels in the operation of railway vehicles. The levels differ in terms of the frequency and the level of advancement of service work. As part of the work performed on the lower maintenance levels, routine works are carried out, e.g. replenishment or replacement of operating fluids. The higher maintenance levels of railway vehicles include specialized servicing and decommissioning repairs. The frequency with which the activities foreseen under the different maintenance levels are performed depends on the type of the trainset. The highest operating costs are generated under the first maintenance level. Table 1 summarizes the computational data and the results of the operating costs of the diesel multiple unit. The unit costs and consumption of fuel and engine oil were adopted on the basis of $[2 \div 5]$. The periods and costs of replacing filters and friction elements of the braking system were estimated on the basis of the analysis of operational data of vehicles equipped with combustion drives. The calculations were made for one year of operation, within which 300 operating days of the vehicle were assumed. The average daily distance travelled by one multiple unit was assumed at the level of $915 \mathrm{~km}$. This value was determined on the basis of an analysis of the timetable of regional vehicles on the Gdynia Główna - Hel route (in the summer season and outside it) and the transport capacity of a single trainset, assuming the daily shutdown of the vehicle for 2 hours.

The cost of operating the unit powered from the electric network is mainly related to the cost of electricity and the cost of maintaining the catenary network, including repairs of damage resulting from atmospheric phenomena. Table 2 summarizes the computational data and the results of the operating costs of the electric multiple unit. The unit cost of electricity was assumed on the basis of [6].

The predominant operating costs of electric storage units are related to the cost of electricity and the need for periodic replacement of traction batteries. As part of the analysis, an assumption was made to replace niepomijalnym kryterium w kontekście niezelektryfikowanej linii 213 przebiegającej przez Półwysep Helski. Modernizacja linii kolejowej 213 nie powinna zakłócić estetyki krajobrazowej Półwyspu Helskiego, co może mieć miejsce w przypadku elektryfikacji tej linii. Równie istotny, jak walory krajobrazowe, jest hałas emitowany przez pojazd trakcyjny.

Kryterium środowiskowe oceny wariantów obsługi trasy odnosi się również do emisji dwutlenku węgla oraz innych szkodliwych substancji do atmosfery. Pojazd z napędem spalinowym emituje do atmosfery substancje szkodliwe w miejscu jego eksploatacji, co jest istotną wadą w kontekście obszaru chronionego programem Natura 2000. W Polsce, gdzie obecnie ponad $80 \%$ energii elektrycznej produkuje się w wyniku spalanie węgla, emisja substancji szkodliwych w wyniku produkcji energii elektrycznej wykorzystywanej do zasilania pojazdów elektrycznych jest o $29 \%$ mniejsza niż emisja mająca miejsce w wyniku eksploatacji pojazdów napędzanych silnikami spalinowymi [1].

\subsection{Kryterium kosztów eksploatacji}

W ramach eksploatacji pojazdów kolejowych wyróżnia się pięć różnych poziomów ich utrzymania. Poziomy różnią się częstotliwością oraz poziomem zaawansowania prac serwisowych. W ramach prac wykonywanych w zakresie niższych poziomów utrzymania wykonywane są rutynowe prace, m.in. uzupełnienie bądź wymiana płynów eksploatacyjnych. Wyższe poziomy utrzymania pojazdów kolejowych obejmują wyspecjalizowane czynności serwisowe oraz naprawy wykonywane podczas wyłączenia pojazdu z eksploatacji.

Częstość wykonywania czynności przewidzianych w ramach różnych poziomów utrzymania uzależniona jest od rodzaju zespołu trakcyjnego. Największe koszty eksploatacji generowane są w ramach pierwszego poziomu utrzymania. $\mathrm{W}$ tablicy 1 zestawiono dane obliczeniowe oraz wyniki kosztów eksploatacji spalinowego zespołu trakcyjnego. Jednostkowe koszty i zużycie paliwa oraz oleju silnikowego przyjęto na podstawie $[2 \div 5]$. Okresy i koszty wymiany filtrów oraz elementów ciernych układu hamulcowego oszacowano na podstawie analizy danych eksploatacyjnych pojazdów wyposażonych w napędy spalinowe. Obliczenia wykonano dla jednego roku eksploatacji, w ramach którego przyjęto 300 dni operacyjnych pojazdu. Średni dzienny dystans pokonywany przez jeden zespół trakcyjny przyjęto na poziomie $915 \mathrm{~km}$. Wartość tę określono na podstawie analizy rozkładu jazdy pojazdów regionalnych na trasie Gdynia Główna - Hel (w sezonie letnim oraz poza nim) oraz możliwościach transportowych pojedynczego zespołu trakcyjnego przy założeniu dziennego wyłączenia pojazdu z ruchu przez 2 godziny.

Koszt eksploatacji zespołu zasilanego z sieci elektrycznej związany jest głównie z kosztem energii elektrycznej oraz kosztem utrzymania sieci trakcyj- 
the battery bank after 10 years of operation. The cost of the new battery was included in the annual operating costs of the vehicle. An important factor increasing the operating costs of storage traction units is the operating cost of the converter system cooling systems. This cost is mainly related to the periodic replacement of fan air filters. Table 3 summarizes the computational data and the results of operating costs of the storage multiple unit. The cost and period of replacement of the air filter of the fan of the power electronic converter cooling system were estimated on the basis of the analysis of operating costs of fan cooling systems.

\section{Summary of the DMU calculation data and operating costs} Table 1

Zestawienie danych obliczeniowych oraz kosztów eksploatacji s.z.t. Tablica 1

\begin{tabular}{|l|c|}
\hline Unit diesel fuel cost & 3.37 PLN/litre \\
\hline Unit diesel fuel consumption & 50 litre/100 km \\
\hline Unit cost of engine oil & 11.36 PLN/litre \\
\hline Unit oil consumption & $0.3 \%$ of fuel consumption \\
\hline The cost of replacing the oil filter & 120 PLN \\
\hline Filter and engine oil change period & $1 / 200000 \mathrm{~km}$ \\
\hline The cost of replacing the air filter & 500 PLN \\
\hline Air filter replacement period & $1 / 100000 \mathrm{~km}$ \\
\hline $\begin{array}{l}\text { The cost of replacing the friction } \\
\text { elements of the brake system }\end{array}$ & 12600 PLN \\
\hline $\begin{array}{l}\text { The period of replacement of the } \\
\text { friction elements of the brake } \\
\text { system }\end{array}$ & $1 / 100000 \mathrm{~km}$ \\
\hline \multicolumn{2}{|c|}{ Expenditure } \\
\hline \begin{tabular}{l} 
Diesel fuel \\
\hline Engine oil
\end{tabular} & 137591 litres \\
\hline $\begin{array}{l}\text { The cost of replacing the friction } \\
\text { elements of the brake system }\end{array}$ & 504 980 PLN litres \\
\hline Total cost & 563405 PLN \\
\hline The cost of diesel fuel & 5468 PLN \\
\hline Het cost of engine oil & 1536 PLN \\
\hline \begin{tabular}{l} 
air filters replacing engine oil and \\
\hline
\end{tabular} & 3469 PLN \\
\hline
\end{tabular}

nej, uwzględniającym naprawy uszkodzeń powstających w wyniku zjawisk atmosferycznych. W tablicy 2 zestawiono dane obliczeniowe oraz wyniki kosztów eksploatacji elektrycznego zespołu trakcyjnego. Jednostkowy koszt energii elektrycznej przyjęto na podstawie [6].

Przeważające koszty eksploatacji elektrycznych zespołów zasobnikowych związane są z kosztem energii elektrycznej oraz z koniecznością okresowej wymiany akumulatorów trakcyjnych. W ramach analizy przyjęto założenie wymiany baterii akumulatorów po 10 latach eksploatacji. Koszt nowej baterii został wliczony w roczne koszty eksploatacji pojazdu. Istotnym czynnikiem zwiększającym koszty eksploatacji zasobnikowych zespołów trakcyjnych jest koszt eksploatacji systemów chłodzenia układów przekształtnikowych. Koszt ten związany jest głównie $\mathrm{z}$ okresową wymianą filtrów powietrza wentylatorów. W tablicy 3 zestawiono dane obliczeniowe oraz wyniki kosztów eksploatacji zasobnikowego zespołu trakcyjnego. Koszt oraz okres wymiany filtru powietrza wentylatora systemu chłodzenia przekształtnika energoelektronicznego oszacowano na podstawie analizy kosztów eksploatacji wentylatorowych systemów chłodzenia.

\section{Summary of the EMU calculation data and operating costs Table 2}

Zestawienie danych obliczeniowych oraz kosztów eksploatacji e.z.t. Tablica 2

\begin{tabular}{|l|c|}
\hline \multicolumn{2}{|c|}{ Calculation data } \\
\hline Unit cost of electricity & $0.24 \mathrm{PLN} / \mathrm{kWh}$ \\
\hline $\begin{array}{l}\text { Unit cost of maintaining the cate- } \\
\text { nary network }\end{array}$ & $15,000 \mathrm{PLN} / \mathrm{km}$ \\
\hline \multicolumn{2}{|c|}{ Expenditure } \\
\hline $\begin{array}{l}\text { Average energy demand on the } \\
\text { route }\end{array}$ & $2.98 \mathrm{kWh} / \mathrm{km}$ \\
\hline Total electricity consumption & $817,625 \mathrm{kWh}$ \\
\hline \multicolumn{2}{|c|}{ Annual operating costs } \\
\hline Electricity cost & $196,230 \mathrm{PLN}$ \\
\hline $\begin{array}{l}\text { The cost of maintaining the cate- } \\
\text { nary }\end{array}$ & $924,300 \mathrm{PLN}$ \\
\hline Total cost & $\mathbf{1 , 1 2 0 , 5 3 0 ~ P L N ~}$ \\
\hline
\end{tabular}

\begin{tabular}{|l|c|}
\hline \multicolumn{2}{|c|}{ Calculation data } \\
\hline Unit cost of electricity & 0.24 PLN \\
\hline Mileage to replace the fan air filter & $50,000 \mathrm{~km}$ \\
\hline Cost of replacing the fan air filter & $500 \mathrm{PLN}$ \\
\hline \multicolumn{2}{|c|}{ Expenditure } \\
\hline Average energy demand on the route & $3.16 \mathrm{kWh} / \mathrm{km}$ \\
\hline Total electricity consumption & $868,149 \mathrm{kWh}$ \\
\hline \multicolumn{2}{|c|}{ Annual operating costs } \\
\hline Electricity cost & $208,356 \mathrm{PLN}$ \\
\hline Cost of battery replacement & $214,673 \mathrm{PLN}$ \\
\hline Cost of replacing the fan air filter & 2,744 PLN \\
\hline Total cost & $\mathbf{4 2 5 , 7 7 1 ~ P L N ~}$ \\
\hline
\end{tabular}

Summary of the IPEMU calculation data and operating costs Table 3

Zestawienie danych obliczeniowych oraz kosztów eksploatacji z.e.z.t. Tablica 3 


\subsection{Investment criterion}

The investment criterion covers all costs of modernization of line 213 and the purchase or modernization of rolling stock. As part of this criterion, the common costs of modernization of lines were taken into account, including the costs of building passing passes at the stations discussed in [11], aimed at increasing the line capacity. The costs determined on the basis of $[7,8]$ are presented in Table 4 .

\subsection{Kryterium inwestycyjne}

Inwestycyjne kryterium obejmuje wszelkie koszty modernizacji linii 213 oraz zakupu bądź modernizacji taboru. W ramach tego kryterium uwzględnione zostały wspólne koszty modernizacji linii obejmujące koszty budowy mijanek na stacjach omówionych w [11], mających na celu zwiększenie przepustowości linii. Koszty określone na podstawie $[7,8]$ zestawiono w tablicy 4 .
Summary of common costs of modernization of line 213

Zestawienie wspólnych kosztów modernizacji linii 213
Table 4

Tablica 4

\begin{tabular}{|l|l|c|}
\hline \multicolumn{1}{|c|}{ Description } & \multicolumn{1}{c|}{ Quantity } & Cost \\
\hline One-edge platform, 200 m long, 5 m wide & 1 & $1,470,797$ PLN \\
\hline Double-edged platform, 200 m long, 5 m wide & 1 & $1,792,858$ PLN \\
\hline 3.1 class track & $2250 \mathrm{~m}$ & $4,011,875$ PLN \\
\hline Class 3.1 track turnout & 10 & $3,258,944$ PLN \\
\hline Footpath & $60 \mathrm{~m}$ & 64,159 PLN \\
\hline Lighting of pedestrian routes and platforms & - & 172,800 PLN \\
\hline Railway traffic control system & - & $3,047,880$ PLN \\
\hline Total cost & & $\mathbf{6 , 5 8 6 , 7 5 8}$ PLN \\
\hline
\end{tabular}

The operation of the partially electrified Gdynia Główna - Hel route with the use of diesel multiple units does not involve the costs of purchasing rolling stock, as this route has been operated in regional traffic since 2010 by diesel units SA137 and SA138 type of the Newag company. For the analysis of investment costs of route operation by DMU common costs of modernization of line 213 were assumed for all variants presented in Table 4 .

The use of electric multiple units for route service requires the electrification of line 213 and the purchase of the required number of multiple units. According to the current summer timetable, 16 journeys are carried out each day on the route Gdynia Główna - Hel and Hel - Gdynia Główna. Taking into account the travel time on this route in the summer season and the vehicle's operation around the clock, it is necessary to purchase 3 multiple units. The considerations were based on the use of the Flirt electric multiple unit from Stadler, the modernized version of which was proposed for the line service as IPEMU. The electrification of line 213 requires the construction of two traction substations in order to supply the line and maintain the required voltage level. The construction of the first substation is proposed in Władysławowo, where a $110 \mathrm{kV}$ high voltage line runs in close proximity to line 213 . Hel is proposed as the location of the second traction substation, however, this solution requires a $35 \mathrm{~km}$ cable connection from the Władysławowo 110/30/15 kV substation. Table 5 summarizes the costs determined on the basis of $[7,8]$ related to the electrification of line 213 and the total cost of servicing the route with the use of electric multiple units.
Obsługa częściowo zelektryfikowanej trasy Gdynia Główna - Hel przy wykorzystaniu spalinowych zespołów trakcyjnych nie wiąże się z kosztami zakupu taboru, gdyż trasa ta od 2010 roku w ruchu regionalnym obsługiwana jest przez jednostki spalinowe SA137 oraz SA138 f-my Newag. Do analizy kosztów inwestycyjnych obsługi trasy przez s.z.t. przyjęto koszty wspólne modernizacji linii 213 dla wszystkich wariantów przedstawione w tablicy 4.

Wykorzystanie do obsługi trasy elektrycznych zespołów trakcyjnych wiąże się z koniecznością elektryfikacji linii 213 oraz zakupem wymaganej liczby zespołów trakcyjnych. Zgodnie z aktualnie obowiązującym letnim rozkładem jazdy każdego dnia realizowanych jest 16 kursów na trasie Gdynia Główna - Hel oraz Hel - Gdynia Główna. Przy uwzględnieniu czasu przejazdu na tej trasie $\mathrm{w}$ sezonie letnim oraz pracy pojazdu przez całą dobę konieczny jest zakup 3 zespołów trakcyjnych. Rozważania oparto na zastosowaniu elektrycznego zespołu trakcyjnego Flirt f-my Stadler, którego zmodernizowana wersja zaproponowana została do obsługi linii jako z.e.z.t. Elektryfikacja linii 213 wiąże się $z$ koniecznością budowy dwóch podstacji trakcyjnych w celu zasilania linii oraz utrzymania wymaganego poziomu napięcia. Budowę pierwszej podstacji proponuje się w miejscowości Władysławowo, gdzie w bliskiej odległości od linii 213 przebiega linia wysokiego napięcia $110 \mathrm{kV}$. Jako lokalizację drugiej podstacji trakcyjnej proponuje się miejscowość Hel, jednakże rozwiązanie to wiąże się z koniecznością doprowadzenia połączenia kablowego o długości $35 \mathrm{~km}$ ze stacji elektroenergetycznej Władysławowo $110 / 30 / 15 \mathrm{kV}$. W tablicy 5 zestawiono określone na podstawie $[7,8]$ koszty związane z elektryfikacją linii 213 oraz łączny koszt obsługi trasy przy wykorzystaniu elektrycznych zespołów trakcyjnych. 
List of investment costs of route maintenance by EMU $[7,8]$ Table 5

Zestawienie kosztów inwestycyjnych obsługi trasy przez e.z.t. Tablica 5

\begin{tabular}{|l|c|}
\hline \multicolumn{2}{|c|}{ Construction of the catenary } \\
\hline $\begin{array}{l}\text { Installation of supporting structures with } \\
\text { foundations }\end{array}$ & 318,937 PLN \\
\hline Installation of net suspensions & 63,039 PLN \\
\hline Installation of net anchoring & 18,303 PLN \\
\hline Installation of network cables & 378,111 PLN \\
\hline $\begin{array}{l}\text { Installation of electrical connections and } \\
\text { splice circuits }\end{array}$ & 4,632 PLN \\
\hline Network regulation & 12,710 PLN \\
\hline Cost of 1 km of the network & 795,731 PLN \\
\hline Cost of 62.61 km of the network & $49,032,964$ PLN \\
\hline \multicolumn{2}{|c|}{ Total investment cost } \\
\hline $\begin{array}{l}\text { Construction of traction substations } \\
\text { Władysławowo and Hel }\end{array}$ & $6,000,000$ PLN \\
\hline $\begin{array}{l}\text { Construction of a 15 kV cable line to } \\
\text { power the Hel traction substation }\end{array}$ & $15,848,94$ PLN \\
\hline Cost & $49,032,964$ PLN \\
\hline \multicolumn{2}{|c|}{$21,848,945$ PLN } \\
\hline Construction of the traction network \\
\hline Construction of traction substations \\
\hline $\begin{array}{l}\text { Purchase of 3 Flirt electric multiple } \\
\text { units from Stadler }\end{array}$ & $108,195,000$ PLN \\
\hline Common line upgrade costs & $\mathbf{1 8 5 , 6 6 3 , 6 6 7 ~ P L N ~}$ \\
\hline Total cost & $1,96,758$ PLN \\
\hline
\end{tabular}

The introduction of storage multiple units to the route is associated with the construction of a charging station in Hel. Requirements for the parameters of the charging station are presented in [11]. In order to ensure the required power of the charging station of $1.2 \mathrm{MW}$, it is necessary to build a cable line with a rated voltage of $15 \mathrm{kV}$, supplying electricity from the 110/30/15 kV power station Władysławowo. As part of this study, the use of Stadler's modernized Flirt electric multiple units, equipped with an onboard battery bank and a supercapacitor was proposed for the operation of the analyzed route. As in the case of route operation with the use of electric units, in order to ensure the required operability, the purchase of 3 units is assumed. Table 6 presents the costs of route servicing with the use of storage trains prepared on the basis of $[7,8]$.

\section{MULTICRITERIAL DECISION MODEL}

In order to indicate the best option for servicing the partially electrified Gdynia Główna - Hel route, a multi-criteria decision model was used [10]. This model was built using the VIKOR method, which consisted of measuring the divergence of a given analysis variant from the assumed ideal scenario. In this method, the evaluation criteria of the considered variants are normalized, which enables the criteria of various measures and the desired values to be compared with each other. These criteria are assigned spe-
Wprowadzenie do obsługi trasy zasobnikowych zespołów trakcyjnych wiąże się z budową stacji ładowania w miejscowości Hel. Wymagania dotyczące parametrów stacji ładowania przedstawiono w [11]. W celu zapewnienia wymaganej mocy stacji ładowania wynoszacej 1,2 MW konieczna jest budowa linii kablowej o napięciu znamionowym $15 \mathrm{kV}$ dostarczającej energię elektryczną ze stacji elektroenergetycznej Władysławowo 110/30/15 kV. W ramach niniejszej pracy do obsługi analizowanej trasy zaproponowano zastosowanie zmodernizowanych elektrycznych zespołów trakcyjnych Flirt f-my Stadler, wyposażonych $\mathrm{w}$ pokładową baterię akumulatorów oraz superkondensator. Tak jak w przypadku obsługi trasy przy wykorzystaniu zespołów elektrycznych, w celu zapewnienia wymaganej operatywności, przyjmuje się zakup 3 zespołów. Tablica 6 przedstawia zestawienie kosztów obsługi trasy przy wykorzystaniu zasobnikowych zespołów trakcyjnych przygotowanych na podstawie $[7,8]$.

List of investment costs of route maintenance by IPEMU $[7,8]$

Table 6

Zestawienie kosztów inwestycyjnych obsługi trasy przez z.e.z.t. $[7,8]$

Tablica 6

\begin{tabular}{|l|c|}
\hline $\begin{array}{l}\text { Purchase of 3 Flirt electric multiple units } \\
\text { from Stadler }\end{array}$ & $92,957,746$ PLN \\
\hline Installation of on-board energy storage & $22,781,700$ PLN \\
\hline Construction of the Hel charging station & $3,000,000$ PLN \\
\hline $\begin{array}{l}\text { Construction of a 15 kV cable line to } \\
\text { power the Hel traction substation }\end{array}$ & $15,848,945$ PLN \\
\hline Common railway upgrade costs & $6,586,758$ PLN \\
\hline Total cost & $\mathbf{1 4 1 , 1 7 5 , 1 4 9 ~ P L N ~}$ \\
\hline
\end{tabular}

\section{WIELOKRYTERIALNY MODEL DECY- ZYJNY}

W celu wskazania najlepszego wariantu obsługi częściowo zelektryfikowanej trasy Gdynia Główna - Hel posłużono się wielokryterialnym modelem decyzyjnym [10]. Model ten zbudowano metoda VIKOR, polegającej na pomiarze rozbieżności danego wariantu analizy od zakładanego scenariusza idealnego. W metodzie tej kryteria oceny rozpatrywanych wariantów podlegają normalizacji, umożliwiającej konfrontowanie ze sobą kryteriów różnych miar oraz pożądanych wartości. Kryteriom tym przypisuje się określone wagi w zależności od oczekiwań stawianym modernizowanej trasie $\mathrm{w}$ ramach scenariuszy. $\mathrm{W}$ ramach analizy obliczane są wskaźniki rankingowe odwzorowujące poziom dopasowania danego wariantu obsługi trasy do przewidzianego scenariusza idealnego. Na podstawie wartości wskaźników tworzona jest tablica wyników analizy przedstawiająca ranking rozpatrywanych wariantów analizy. Metodologia podejmowania decyzji przedstawiona jest na rys. 1. 
cific weights depending on the expectations of the modernized route under the scenarios. As part of the analysis, ranking indicators are calculated reflecting the level of adjustment of a given route service variant to the predicted ideal scenario. Based on the values of the indicators, an analysis results table is created, presenting the ranking of the analyzed variants of the analysis. The decision-making methodology is presented in Fig. 1.

In the first stage of the calculations made as part of the multi-criteria analysis, Table 7 lists the variants of the analysis and the criteria for their evaluation. This table presents the evaluation criteria in a non-standardized form, which means that the units of the evaluation criteria are different and it is impossible to compare the route service variants at this stage.

In order to standardize the evaluation criteria of the modernization variants, the spread coefficient of the criterion function is calculated:

where:

$$
d_{i j}=\frac{f_{i}^{*}-f_{i j}}{f_{i}^{*}-f_{i}^{-}}
$$

$d_{i j}-$ spread coefficient of the criterion function [],

$f_{i j}-\mathrm{i}$-th criterion function for $\mathrm{j}$-th alternative solution $[-]$,

$f_{i}^{*}$ - the maximum value of $f_{i j}$ when the i-th criterion function shows an advantage, the minimum value of $f_{i j}$ when the $\mathrm{i}$-th criterion function shows a disadvantage $[-]$,

$f_{i}^{-}$- the minimum value of $f_{i j}$ when the i-th criterion function shows an advantage, the maximum value of $f_{i j}$ when the $i$-th criterion function shows an advantage [-].

Table 8 presents the normalized values of the criteria for assessing the variants of the Gdynia Główna - Hel route service. At this stage of the analysis, it is possible to evaluate the modernization options against individual criteria.

Variants of analysis and evaluation criteria Warianty analizy oraz kryteria oceny

Table 7

\begin{tabular}{|c|c|c|c|}
\hline & SR [point] & EE [PLN] & EI [PLN] \\
\hline DMU & 1 & 504,979 & $6,586,758$ \\
\hline EMU & 2 & $1,120,529$ & $185,663,667$ \\
\hline IPEMU & 3 & 425,770 & $141,175,149$ \\
\hline
\end{tabular}

Standardized variants of the analysis and evaluation criteria

Table 8

Znormalizowane warianty analizy i kryteria oceny Tablica 8

\begin{tabular}{|c|c|c|c|}
\hline & SR & EE & EI \\
\hline DMU. & 1.00 & 0.11 & 0.00 \\
\hline EMU & 0.50 & 1.00 & 1.00 \\
\hline IPEMU & 0.00 & 0.00 & 0.75 \\
\hline
\end{tabular}

\section{Tablica 7}

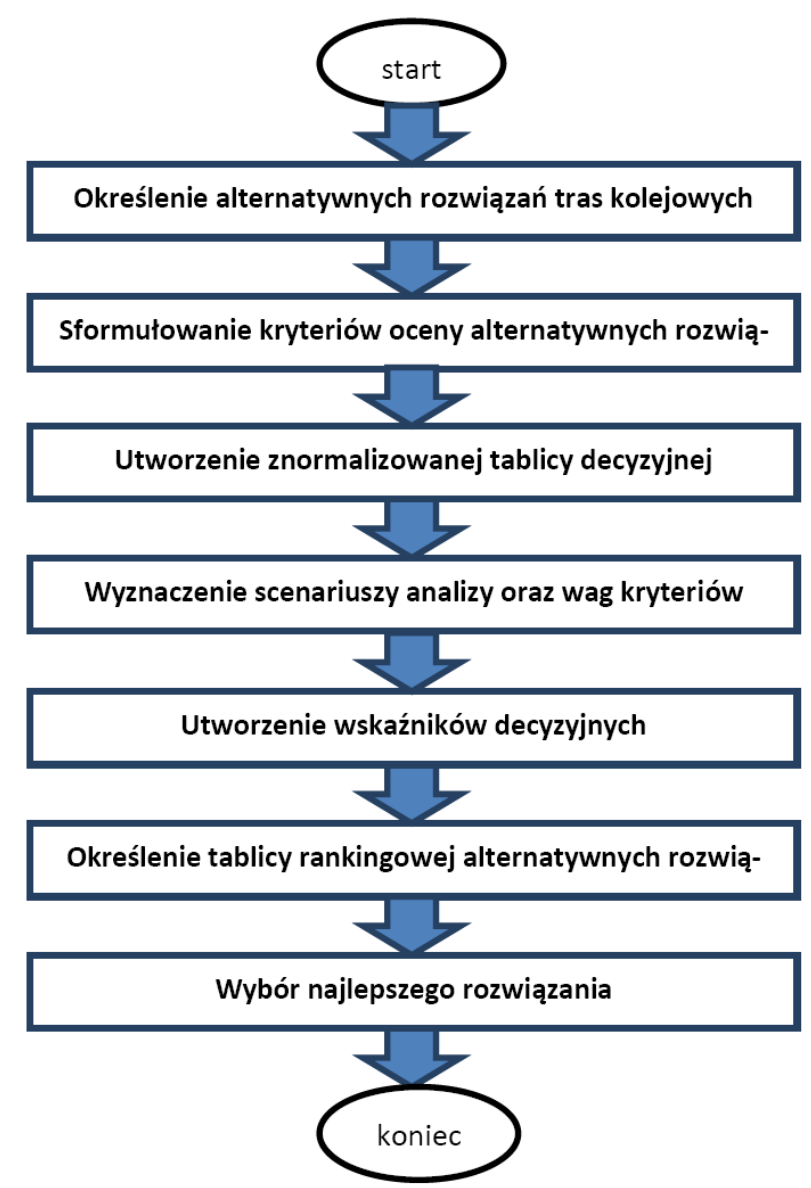

Fig. 1. Methodology of making decisions in a multi-criteria decision model

Rys. 1. Metodologia podejmowania decyzji wielokryterialnego modelu decyzyjnego

W pierwszym etapie obliczeń wykonanych w ramach analizy wielokryterialnej $\mathrm{w}$ tablicy 7 zestawiono warianty analizy oraz kryteria ich oceny. Tablica ta przedstawia kryteria oceny w formie nieznormalizowanej, co oznacza, że jednostki kryteriów oceny są różne i porównanie wariantów obsługi trasy na tym etapie jest niemożliwe.

W celu znormalizowania kryteriów oceny wariantów modernizacji obliczany są jest współczynnik rozpiętości funkcji kryterialnej $d_{i j}$

gdzie:

$$
d_{i j}=\frac{f_{i}^{*}-f_{i j}}{f_{i}^{*}-f_{i}^{-}}
$$

$d_{i j}$ - współczynnik rozpiętości funkcji kryterialnej [-]

$f_{i j}$-wartość i-tej funkcji kryterialnej dla j-tego rozwiązania alternatywnego [-]

$f_{i}^{*}$ - wartość maksymalna $f_{i j}$ gdy i-ta funkcja kryterialna wykazuje korzyść, wartość minimalna gdy $f_{i j}$ i-ta funkcja kryterialna wykazuje niekorzyść [-]

$f_{i}^{-}$- wartość maksymalna $f_{i j}$ gdy i-ta funkcja kryterialna wykazuje korzyść, wartość minimalna gdy $f_{i j}$ i-ta funkcja kryterialna wykazuje niekorzyść [-]. 
The next stage of the multi-criteria analysis is to define scenarios in which the assessment criteria are assigned specific weights, the sum of which in each scenario is equal to 10 . As part of the analysis, the following four scenarios are envisaged:

- $\mathrm{SRSC}_{\mathrm{SC}}$ - the most important is the environmental criterion, the economic criteria are of equal weight (environmental scenario),

- EIsc - the most important is the economic investment criterion, the operational economic criterion and the environmental criterion have equal weight (investment scenario),

- $\mathrm{EE}_{\mathrm{SC}}$ - the most important is the operational economic criterion, the investment economic criterion and the environmental criterion are of equal weight (operational scenario),

- RWsc - all criteria have equal weights (equal weighting scenario).

Table 9 presents a list of multi-criteria analysis scenarios and the corresponding weights of the criteria.

The next stage of calculations in the multicriteria analysis is the calculation of the compromise ranking indicators $S_{j}$ and $R_{j}$, which will be used to calculate the unified ranking indicator $Q_{j}$. These indicators are calculated on the basis of the dependence:

$$
\begin{array}{r}
S_{j}=\sum_{i=1, j=1}^{i=n, j=m} \frac{w_{i}\left(f_{i}^{*}-f_{i j}\right)}{\left(f_{i}^{*}-f_{i}^{*}\right)} \\
R_{j}=\max \frac{w_{i}\left(f_{i}^{*}-f_{i j}\right)}{\left(f_{i}^{*}-f_{i}^{-}\right)}
\end{array}
$$

where:

$S_{j}, R_{j} \quad$ - compromise ranking indicators [-],

$w_{i}$ - the weighting factor of the given criterion [-],

$f_{i j}$ - the value of the $\mathrm{i}$-th criterion function for the $\mathrm{j}$-th alternative solution [-],

$f_{i}^{*}$ - maximum value of $f_{i j}$ when the i-th criterion function shows an advantage, minimum value of $f_{i j}$ when $\mathrm{i}$-th criterion function shows a disadvantage [-],

$f_{i}^{-}-$minimum value of $f_{i j}$ when the $\mathrm{i}$-th criterion function shows an advantage, maximum value of $f_{i j}$ when i-th criterion function shows a disadvantage $[-]$.

Table 10 shows a summary of the calculated values of the compromise ranking coefficients $S_{j}$ and $R_{j}$.

In order to determine the unified ranking index, it is necessary to calculate the coefficients of the ranges of the ranking indicators $Q S_{j}$ and $Q R_{j}$. These coefficients are determined on the basis of the dependence:

$$
Q S_{j}=\frac{s_{j}-s^{*}}{s^{-}-s^{*}}
$$

W tablicy 8 przedstawiono znormalizowane wartości kryteriów oceny wariantów obsługi trasy Gdynia Główna - Hel. Na tym etapie analizy możliwa jest ocena wariantów modernizacji względem poszczególnych kryteriów.

Kolejnym etapem analizy wielokryterialnej jest określenie scenariuszy, w ramach których kryteriom oceny przypisywane są określone wagi, których suma w każdym scenariuszu jest równa 10 . W ramach przeprowadzonej analizy przewidziano cztery następujące scenariusze:

- $\mathrm{SR}_{\mathrm{SC}}$ - najważniejsze jest kryterium środowiskowe, kryteria ekonomiczne mają równe wagi (scenariusz środowiskowy)

- $\mathrm{EI}_{\mathrm{SC}}$ - najważniejsze jest kryterium ekonomiczne inwestycyjne, kryterium ekonomiczne eksploatacyjne oraz kryterium środowiskowe mają równe wagi (scenariusz inwestycyjny),

- $\quad \mathrm{EE}_{\mathrm{SC}}$ - najważniejsze jest kryterium ekonomiczne eksploatacyjne, kryterium ekonomiczne inwestycyjne oraz kryterium środowiskowe mają równe wagi (scenariusz eksploatacyjny)

- $\mathrm{RW}_{\mathrm{SC}}$ - wszystkie kryteria mają równe wagi (scenariusz równych wag).

W tablicy 9 przedstawiono zestawienie scenariuszy analizy wielokryterialnej oraz odpowiadających im wag kryteriów.

Następnym etapem obliczeń w ramach analizy wielokryterialnej jest obliczenie wskaźników rankingu kompromisowego $S_{j}$ oraz $R_{j}$, które wykorzystane zostaną do obliczenia zunifikowanego wskaźnika rankingowego $Q_{j}$. Wskaźniki te obliczane sạ na podstawie zależności:

$$
\begin{gathered}
S_{j}=\sum_{i=1, j=1}^{i=n, j=m} \frac{w_{i} \cdot\left(f_{i}^{*}-f_{i j}\right)}{\left(f_{i}^{*}-f_{i}^{-}\right)} \\
R_{j}=\max \frac{w_{i} \cdot\left(f_{i}^{-}-f_{i j}\right)}{\left(f_{i}^{*}-f_{i}^{-}\right)}
\end{gathered}
$$

gdzie:

$S_{j}, R_{j}$ - wskaźniki rankingu kompromisowego [-],

$w_{i}$ - wspólczynnik wagowy danego kryterium $[-]$,

$f_{i j}$ - wartość i-tej funkcji kryterialnej dla j-tego rozwiązania alternatywnego [-],

$f_{i}^{*}$ - wartość maksymalna $f_{i j}$ gdy i-ta funkcja kryterialna wykazuje korzyść, wartość minimalna gdy $f_{i j}$ i-ta funkcja kryterialna wykazuje niekorzyść [-], $f_{i}^{-}$- wartość minimalna $f_{i j}$ gdy i-ta funkcja kryterialna wykazuje korzyść, wartość maksymalna gdy $f_{i j}$ i-ta funkcja kryterialna wykazuje niekorzyść [-].

Tablica 10 przedstawia zestawienie obliczonych wartości współczynników rankingu kompromisowego $S_{j}$ oraz $R_{j}$. 
where:

$Q S_{j}$ - range factor of the ranking indicator $S_{j}[-]$,

$S_{j}$ - compromise ranking indicator $[-]$,

$S^{*} \quad$ the minimum value of the indicator $S_{j}[-]$,

$S^{-}$- the maximum value of the indicator $S_{j}[-]$

where:

$$
Q R_{j}=\frac{R_{j}-R^{*}}{R^{-}-R^{*}}
$$

$Q R_{j} \quad$ - range factor of the ranking indicator $R_{j}[-]$,

$R_{j} \quad$ - compromise ranking indicator $[-]$,

$R^{*} \quad-$ the minimum value of the indicator $S_{j}[-]$,

$R^{-} \quad$ - the maximum value of the indicator $S_{j}[-]$.

Based on formula (6), a unified ranking index is calculated $Q_{j}$. The lower its value, the more advantageous a given variant of the railway route service is, according to the selected analysis scenario $S_{j}$ and $R_{j}$, and the unified ranking index $Q_{j}$.

$$
Q_{j}=v \cdot Q S_{j}+(1-v) \cdot Q R_{j}
$$

where:

$Q_{j}$ - unified ranking index [-],

$v$ - the importance of the decision strategy [-],

$Q S_{j}$ - range factor of the ranking indicator $S_{j}[-]$,

$Q R_{j}$ - range factor of the ranking indicator $R_{j}[-]$.

Weights of the criteria of the analysis scenarios Table 9 Wagi kryteriów scenariuszy analizy Tablica 9

\begin{tabular}{|c|c|c|c|c|}
\hline \multirow{2}{*}{ Criteria } & \multicolumn{4}{|c|}{ Scenarios } \\
\cline { 2 - 5 } & $\mathbf{S R}_{\text {SC }}$ & $\mathbf{E I ~ I}_{\text {SC }}$ & $\mathbf{E E}_{\text {SC }}$ & $\mathbf{R W}_{\text {SC }}$ \\
\hline SR & 6.00 & 2.00 & 2.00 & 3.33 \\
\hline EE & 2.00 & 2.00 & 6.00 & 3.33 \\
\hline EI & 2.00 & 6.00 & 2.00 & 3.33 \\
\hline
\end{tabular}

Standardized variants of the analysis and evaluation criteria

Table 10

Znormalizowane warianty analizy i kryteria oceny Tablica 10

\begin{tabular}{|c|c|c|c|c|}
\hline \multirow{2}{*}{ Scenario } & \multirow{2}{*}{ Indicator } & \multicolumn{3}{|c|}{ Variant } \\
\cline { 3 - 5 } & & DMU & EMU & IPEMU \\
\hline \multirow{2}{*}{$\mathrm{SR}_{\mathrm{SC}}$} & $\mathrm{Sj}$ & 6.23 & 7.00 & 1.50 \\
\cline { 2 - 5 } & $\mathrm{Rj}$ & 6.00 & 3.00 & 1.50 \\
\hline \multirow{3}{*}{$\mathrm{EI}_{\mathrm{SC}}$} & $\mathrm{Sj}$ & 2.23 & 9.00 & 4.51 \\
\cline { 2 - 5 } & $\mathrm{Rj}$ & 2.00 & 6.00 & 4.51 \\
\hline \multirow{2}{*}{$\mathrm{EE}_{\mathrm{SC}}$} & $\mathrm{Sj}$ & 2.68 & 9.00 & 1.50 \\
\cline { 2 - 5 } & $\mathrm{Rj}$ & 2.00 & 6.00 & 1.50 \\
\hline \multirow{2}{*}{$\mathrm{RW}_{\mathrm{SC}}$} & $\mathrm{Sj}$ & 3.71 & 8.33 & 2.50 \\
\cline { 2 - 5 } & $\mathrm{Rj}$ & 3.33 & 3.33 & 2.50 \\
\hline
\end{tabular}

W celu wyznaczenia zunifikowanego wskaźnika rankingowego konieczne jest obliczenie wspó1czynników zakresów wskaźników rankingowych $Q S_{j}$ oraz $Q R_{j}$. Wspólczynniki te wyznaczane są na podstawie zależności:

$$
Q S_{j}=\frac{s_{j}-s^{*}}{s^{-}-s^{*}}
$$

gdzie:

$Q S_{j}$ - wspólczynnik zakresu wskaźnika rankingowego $S_{j}[-]$,

$S_{j} \quad$ - wskaźnik rankingu kompromisowego [-],

$S^{*}$ - wartość minimalna wskaźnika $S_{j}[-]$,

$S^{-}$- wartość maksymalna wskaźnika $S_{j}[-]$.

$$
Q R_{j}=\frac{R_{j}-R^{*}}{R^{-}-R^{*}}
$$

gdzie:

$Q R_{j}$ - współczynnik zakresu wskaźnika rankingowego $R_{j}[-]$,

$R_{j}$ - wskaźnik rankingu kompromisowego [-],

$R^{*}$ - wartość minimalna wskaźnika $S_{j}[-]$,

$R^{-}$- wartość maksymalna wskaźnika $S_{j}[-]$.

Na podstawie zależności (6) obliczany jest zunifikowany wskaźnik rankingowy $Q_{j}$. Im niższa jest jego wartość, tym korzystniejszy jest dany wariant obslugi trasy kolejowej wedlug wybranego scenariusza analizy. W tablicy 11. zestawiono obliczone wartości wspólczynników zakresu rankingowego $S_{j}$ oraz $R_{j}$ oraz zunifikowanego wskaźnika rankingowego $Q_{j}$.

$$
Q_{j}=v \cdot Q S_{j}+(1-v) \cdot Q R_{j}
$$

gdzie:

$Q_{j}$ - zunifikowany wskaźnik rankingowy [-]

$v \quad$ - waga strategii decyzyjnej [-]

$Q S_{j}$ - współczynnik zakresu wskaźnika rankingowean $S=$ r-1

$Q R_{j}$ - wspólczynnik zakresu wskaźnika rankingowego $R_{j}[-]$

Decision table of multi-criteria analysis

Table 11

Tablica decyzyjna analizy wielokryterialnej

Tablica 11

\begin{tabular}{|c|c|c|c|c|}
\hline \multirow{2}{*}{ Scenario } & \multirow{2}{*}{ Factor } & \multicolumn{3}{|c|}{ Variants } \\
\cline { 2 - 5 } & & IPEMU & EMU & DMU \\
\hline \multirow{3}{*}{$\mathrm{SR}_{\mathrm{SC}}$} & $\mathrm{Qj}$ & 0.93 & 0.67 & 0.00 \\
\cline { 2 - 5 } & $\mathrm{QSj}$ & 0.86 & 1.00 & 0.00 \\
\cline { 2 - 5 } & $\mathrm{QRj}$ & 1.00 & 0.33 & 0.00 \\
\hline \multirow{3}{*}{$\mathrm{EI}_{\mathrm{SC}}$} & $\mathrm{Qj}$ & 0.00 & 1.00 & 0.48 \\
\cline { 2 - 5 } & $\mathrm{QSj}$ & 0.00 & 1.00 & 0.34 \\
\cline { 2 - 5 } & $\mathrm{QRj}$ & 0.00 & 1.00 & 0.63 \\
\hline \multirow{3}{*}{$\mathrm{EE}_{\mathrm{SC}}$} & $\mathrm{Qj}$ & 0.13 & 1.00 & 0.00 \\
\cline { 2 - 5 } & $\mathrm{QSj}$ & 0,16 & 1.00 & 0.00 \\
\cline { 2 - 5 } & $\mathrm{QRj}$ & 0.11 & 1.00 & 0.00 \\
\hline \multirow{3}{*}{$\mathrm{RW}_{\mathrm{SC}}$} & $\mathrm{Qj}$ & 0.60 & 1.00 & 0.00 \\
\cline { 2 - 5 } & $\mathrm{QSj}$ & 0.21 & 1.00 & 0.00 \\
\cline { 2 - 5 } & $\mathrm{QRj}$ & 1.00 & 1.00 & 0.00 \\
\hline
\end{tabular}


Comparison of the values of the unified ranking index $Q_{j}$ calculated for each of the considered options for servicing the Gdynia Glowna - Hel route is insufficient to choose the best solution. According to the VIKOR method, the best alternative from the point of view of multi-criteria criteria is the one that is on the first position in the ranking list for the decision strategy weight value of $v=0,5$ and meets the criteria:

- "sufficient advantage" over the next alternative on the list (condition U1),

- "sufficient position stability" when changing the value of the weight of the decision strategy (condition U2).

The alternative solution has a sufficient advantage over the next solutions from the ranking list when the condition expressed in the relationship is met:

$$
Q\left(V^{\prime \prime}\right)-Q\left(V^{\prime}\right) \geq D Q
$$

where:

$Q\left(V^{\prime \prime}\right)$ - value of the unified ranking index for the second solution on the list [-],

$Q\left(V^{\prime}\right)$ - the value of the unified ranking index for the first solution on the list [-],

$D Q \quad$ - advantage threshold [-].

The threshold of the advantage of the best solution over the next one on the ranking list is calculated using the formula below. The threshold value for the analysis with a small number of considered variants is limited to 0.25 .

where:

$$
D Q=\min \left(0,25 ; \frac{1}{m-1}\right)
$$

$D Q$ - advantage threshold [-],

$m$ - number of alternatives [-].

The best alternative meets the 'sufficient position stability' condition if it meets at least one of the following conditions:

- takes the first position in the ranking list according to $\mathrm{Q}$ for the value of the decision strategy weight of $v=0,25$ and $v=0,75$

- ranks first in the ranking list by QS

- ranks first in the ranking list by QR

Table 12 presents the calculation results for four multi-criteria analysis scenarios.

Ranking table of variants of multi-criteria analysis Table 12

Tablica rankingowa wariantów analizy wielokryterialnej

Tablica 12

\begin{tabular}{|c|c|c|c|c|}
\hline \multirow{2}{*}{ Ranking } & \multicolumn{4}{|c|}{ Scenario } \\
\cline { 2 - 5 } & $\mathbf{S R}_{\mathbf{S C}}$ & $\mathbf{E I}_{\mathbf{S C}}$ & $\mathbf{E E}_{\mathbf{S C}}$ & $\mathbf{R W}_{\mathbf{S C}}$ \\
\hline 1 & $\begin{array}{c}\text { IPEMU } \\
(0.00)\end{array}$ & $\begin{array}{c}\text { DMU } \\
(0.00)\end{array}$ & $\operatorname{IPEMU~(0,00)}$ & $\operatorname{IPEMU~(0,00)}$ \\
\hline 2 & EMU (0.67) & $\begin{array}{c}\text { IPEMU } \\
(0.48)\end{array}$ & $\operatorname{DMU~(0,13)}$ & $\operatorname{DMU~(0,60)}$ \\
\hline 3 & DMU (0.93) & $\begin{array}{c}\text { EMU } \\
(1.00)\end{array}$ & EMU (1,00) & EMU (1,00) \\
\hline
\end{tabular}

Porównanie wartości zunifikowanego wskaźnika rankingowego $Q_{j}$ obliczonego dla każdego z rozpatrywanych wariantów obslugi trasy Gdynia Glowna - Hel, jest niewystarczające do wyboru najlepszego rozwiązania. Zgodnie z metodą VIKOR najlepszą alternatywą z punktu widzenia wielokryterialności jest alternatywa, która znajduje się na pierwszej pozycji listy rankingowej dla wartości wagi strategii decyzyjnej wynoszącej $v=0,5$ oraz spelnia kryteria:

- „wystarczającej przewagi” nad kolejną alternatywą na liście (wanunek $\mathrm{U}_{1}$ )

- „wystarczającej stabilności pozycji” przy zmianie wartości wagi strategii decyzyjnej (warunek $\mathrm{U}_{2}$ ).

Alternatywne rozwiązanie ma wystarczającą przewagę nad kolejnymi rozwiązaniami z listy rankingowej gdy spelniony jest wanunek wyrażony zależnością:

$$
\begin{aligned}
& Q\left(V^{\prime \prime}\right)-Q\left(V^{\prime}\right) \geq D Q \\
& \text { gdzie: } \\
& Q\left(V^{\prime \prime}\right) \text { - wartość zunifikowanego wskaźnika ran- } \\
& \text { kingowego dla drugiego rozwiązania z listy [-], } \\
& Q\left(V^{\prime}\right) \text { - wartość zunifikowanego wskaźnika ran- } \\
& \text { kingowego dla pierwszego rozwiązania z listy [-], } \\
& D Q \text { - próg przewagi [-]. }
\end{aligned}
$$

Próg przewagi najlepszego rozwiązania nad kolejnym na liście rankingowej obliczany jest za pomoca poniższej zależności. Wartość progu dla analizy z niewielką liczbą rozpatrywanych wariantów ograniczana jest do wartości 0,25 .

$$
D Q=\min \left(0,25 ; \frac{1}{m-1}\right)
$$

gdzie

$$
\begin{aligned}
& D Q \text { - próg przewagi [-], } \\
& m \text { - liczba alternatywnych rozwiązań }[-] .
\end{aligned}
$$

Najlepsze alternatywne rozwiązanie spelnia warunek „wystarczającej stabilności pozycji”, jeśli spelnia co najmniej jeden $\mathrm{z}$ nastẹpujących warunków:

- zajmuje pierwszą pozycjẹ na liście rankingowej wedlug Q dla wartości wagi strategii decyzyjnej wynoszącej $v=0,25$ oraz $v=0,75$

- zajmuje pierwszą pozycjẹ na liście rankingowej wedlug QS

- zajmuje pierwszą pozycjẹ na liście rankingowej wedlug QR.

W tablicy 12 przedstawiono wyniki obliczeń dla czterech scenariuszy analizy wielokryterialnej.

\section{ANALIZA WYNIKÓW $Z$ MODELU DE- ZYCYJNEGO}

$\mathrm{Na}$ podstawie wyników analizy wielokryterialnej przedstawionych $\mathrm{w}$ tablicy 12 stwierdzić można, że najkorzystniejszym wariantem obsługi częściowo zelektryfikowanej trasy Gdynia Główna Hel według scenariusza środowiskowego oraz scenariusza równych wag jest wykorzystanie do obsługi 


\section{ANALYSIS OF THE RESULTS FROM THE DECISION MODEL}

Based on the results of the multi-criteria analysis presented in Table 12, it can be concluded that the most advantageous variant of servicing the partially electrified Gdynia Główna - Hel route according to the environmental scenario and the scenario of equal weights is the use of storage units for servicing the route. For both of the above-mentioned scenarios, the use of storage units reservoir teams meets the condition of "sufficient advantage" and the condition of "sufficient position stability". In the case of the operational scenario, the use of storage units is also the best solution, however, it does not meet the condition of "sufficient advantage" over the next alternative on the ranking list. The only scenario where the best solution is not to support the route with storage units is the investment scenario. According to this scenario, the best solution is to use combustion units. The comparative analysis was performed assuming that in the case of route servicing with the use of diesel units, the currently used rolling stock will be maintained. As part of the analysis of the results, an alternative variant of using combustion units was considered, taking into account the replacement of the diesel rolling stock with a new one. The analysis was based on the use of Stadler's 3 Flirt diesel multiple units. The unit cost of this vehicle in the combustion version is PLN 21.6 million. The results of the analysis are presented in Table 13.

\section{Ranking table of variants of multi-criteria analysis taking into account the exchange the DMU Table 13}

Tablica rankingowa wariantów analizy wielokryterialnej $\mathrm{z}$ uwzględnieniem wymiany s.z.t. Tabela 13

\begin{tabular}{|c|c|c|c|c|}
\hline \multirow{2}{*}{ Ranking } & \multicolumn{4}{|c|}{ Scenario } \\
\cline { 2 - 5 } & SR $_{\text {SC }}$ & EI $_{\text {SC }}$ & $\mathbf{E E}_{\mathbf{S C}}$ & RW $_{\mathbf{S C}}$ \\
\hline 1 & $\operatorname{IPEMU}(0.00)$ & $\operatorname{DMU}(0.00)$ & $\operatorname{IPEMU}(0.00)$ & $\operatorname{IPEMU}(0.00)$ \\
\hline 2 & EMU (0.67) & $\operatorname{IPEMU~(0.42)~}$ & DMU (0.14) & DMU (0.61) \\
\hline 3 & DMU (0.93) & DMU (1000) & EMU (1.00) & EMU (1.00) \\
\hline
\end{tabular}

The data presented in Table 13 allow for the conclusion that in the event of considering the replacement of diesel rolling stock, the operation of the Gdynia Główna - Hel route using vehicles of this type is still the most advantageous solution according to the investment scenario while meeting the conditions of the so-called stable advantage.

Considering the results of the multi-criteria analysis, it should be considered which of the presented analysis scenarios is decisive in the case of the partially electrified Gdynia Główna - Hel railway. This route runs through the Hel peninsula, which is a protected area under the Natura 2000 program. The trasy zespołów zasobnikowych. Dla obu z wymienionych scenariuszy zastosowanie zespołów zasobnikowych spełnia warunek ,wystarczającej przewagi” oraz warunek ,wystarczającej stabilności pozycji”. W przypadku scenariusza eksploatacyjnego zastosowanie zespołów zasobnikowych również jest najlepszym rozwiązaniem, jednakże nie spełnia ono warunku „wystarczającej przewagi” nad kolejną alternatywą na liście rankingowej. Jedynym scenariuszem, w którym najlepszym rozwiązaniem nie jest obsługa trasy przy wykorzystaniu zespołów zasobnikowych jest scenariusz inwestycyjny. Według tego scenariusza najlepszym rozwiązaniem jest zastosowanie zespołów spalinowych.

Analizę porównawczą wykonano przyjmując założenie, że w przypadku obsługi trasy przy wykorzystaniu zespołów spalinowych zachowany zostanie obecnie wykorzystywany tabor. W ramach analizy wyników rozpatrzono alternatywny wariant zastosowania zespołów spalinowych uwzględniający wymianę taboru spalinowego na nowy. Do analizy przyjęto wykorzystanie 3 spalinowych zespołów trakcyjnych Flirt f-my Stadler. Jednostkowy koszt tego pojazdu w wersji spalinowej wynosi 21,6 mln zł. Wyniki przeprowadzonej analizy przedstawiono w tablicy 13 .

Dane przedstawione w tablicy 13 pozwalaja na stwierdzenie, iż w przypadku rozpatrzenia wymiany taboru spalinowego obsługa trasy Gdynia Główna - Hel przy wykorzystaniu pojazdów tego typu jest nadal rozwiązaniem najkorzystniejszym według scenariusza inwestycyjnego, spełniając przy tym warunki tzw. stabilnej przewagi.

Rozważając wyniki analizy wielokryterialnej należy rozpatrzeć, który z przedstawionych scenariuszy analizy ma decydujące znaczenie $\mathrm{w}$ przypadku częściowo zelektryfikowanej trasy Gdynia Główna Hel. Trasa ta przebiega przez Półwysep Helski, który jest obszarem chronionym w ramach programu Natura 2000. Walory przyrodnicze oraz krajobrazowe Półwyspu Helskiego czynią go miejscem unikalnym w skali kraju, co skłania do uznania scenariusza środowiskowego za priorytetowy. W ramach tego scenariusza najkorzystniejszym rozwiązaniem, ze spełnieniem warunków tzw. stabilnej przewagi, jest zastosowanie zespołów zasobnikowych. Drugie miejsce w ramach scenariusza środowiskowego zajmuje obsługa trasy przy wykorzystaniu elektrycznych zespołów trakcyjnych. Rozwiązanie to zajmuje jednak niższe pozycje od zastosowania z.e.z.t. według scenariuszy ekonomicznych.

Istotnym wynikiem analizy wielokryterialnej jest wynik uzyskany według scenariusza równych wag. Wynik ten jest szczególny, gdyż scenariusz równych wag jest niezależny od subiektywnej oceny istotności poszczególnych kryteriów oceny mającej miejsce w pozostałych scenariuszach analizy. Według scenariusza równych wag zastosowanie do ob.- 
natural and landscape values of the Hel peninsula make it a unique place on a national scale, which makes it a priority to consider the environmental scenario. Under this scenario, the most advantageous solution, meeting the conditions of the so-called stable advantage is the use of storage units. The second place in the environmental scenario is the route operation with the use of electric multiple units. This solution, however, occupies lower positions than the application of IPEMU according to economic scenarios.

An important result of the multi-criteria analysis is the result obtained according to the equal weights scenario. This result is special because the scenario of equal weights is independent of the subjective assessment of the significance of individual assessment criteria taking place in the other scenarios of the analysis. According to the equal weights scenario, the use of storage trains for the operation of the analyzed route is the most advantageous solution, provided that the conditions of the so-called stable advantage over other variants of the route service is met. On the basis of the presented analysis, it is concluded that the most reasonable variant of servicing the partially electrified Gdynia Główna - Hel route is the use of storage multiple units.

\section{SUMMARY}

This article presents a multi-criteria comparative analysis of the operation of the partially electrified Gdynia Główna - Hel railway by diesel, electric and storage electric multiple units. For the purposes of the analysis in the previous article [11], calculations were made of the theoretical travel and the energy demand of the storage train unit on the nonelectrified section of the analyzed route. An on-board hybrid energy storage was selected, consisting of a battery with an energy of $499.3 \mathrm{kWh}$ and a supercapacitor with an energy of $35.6 \mathrm{kWh}$. The multicriteria analysis was based on three evaluation criteria. As part of the environmental criterion, the environmental impact of each of the route operation options was assessed. The considered variants of the route operation were compared in terms of the emission of harmful substances as a result of the use of a given type of vehicle and the impact of each variant on the landscape values. As part of this criterion, it was found that the most environmentally friendly is the use of storage units. The use of these vehicles to service the route does not involve the construction of a traction network that interferes with the landscape of the Hel peninsula and does not cause local pollution of the natural environment.

The second criterion used is the operational economic criterion, within which the annual operating costs of diesel, electric and storage multiple units were analyzed. It has been shown that the lowest operating costs are characteristic of storage vehicles, sługi analizowanej trasy zasobnikowych zespołów trakcyjnych jest najkorzystniejszym rozwiązaniem przy spełnieniu warunków tzw. stabilnej przewagi nad pozostałymi wariantami obsługi trasy. Na podstawie przedstawionej analizy stwierdza się, że najbardziej zasadnym wariantem obsługi częściowo zelektryfikowanej trasy Gdynia Główna-Hel jest zastosowanie zasobnikowych zespołów trakcyjnych.

\section{PODSUMOWANIE}

W niniejszym artykule przeprowadzono wielokryterialną analizę porównawczą obsługi częściowo zelektryfikowanej trasy Gdynia Główna - Hel przez spalinowe, elektryczne oraz zasobnikowe elektryczne zespoły trakcyjne. Na potrzeby analizy w poprzednim artykule [11] wykonano obliczenia przejazdu teoretycznego oraz zapotrzebowania energetycznego zasobnikowego zespołu trakcyjnego na niezelektryfikowanym odcinku analizowanej trasy. Dobrano pokładowy hybrydowy zasobnik energii składający się z baterii akumulatorów o energii 499,3 $\mathrm{kWh}$ oraz superkondensatora o energii 35,6 kWh.

Przeprowadzoną analizę wielokryterialną oparto na trzech kryteriach oceny. W ramach kryterium środowiskowego oceniono wpływ zastosowania każdego z wariantów obsługi trasy na środowisko naturalne. Rozważane warianty obsługi trasy porównano pod kątem emisji szkodliwych substancji w wyniku użytkowania danego typu pojazdu oraz oceniono wpływ każdego z wariantów na walory krajobrazowe. W ramach tego kryterium stwierdzono, iż najprzyjaźniejsze dla środowiska naturalnego jest zastosowanie zasobnikowych zespołów trakcyjnych. Wykorzystanie do obsługi trasy tych pojazdów nie wiąże się $\mathrm{z}$ budową sieci trakcyjnej ingerującej $\mathrm{W}$ krajobraz Półwyspu Helskiego oraz nie powoduje lokalnego zanieczyszczenia środowiska naturalnego.

Drugim z zastosowanych kryteriów jest kryterium ekonomiczne eksploatacyjne, w ramach którego przeanalizowano roczne koszty użytkowania spalinowych, elektrycznych oraz zasobnikowych zespołów trakcyjnych. Wykazano, że najniższymi kosztami eksploatacji charakteryzują się pojazdy zasobnikowe, dla których koszty te wynoszą 425,8 tys. zł. Najdroższymi w eksploatacji są natomiast elektryczne zespoły trakcyjne. Roczny koszt ich eksploatacji wynosi 1,1 mln zł, co związane jest głównie z kosztem utrzymania infrastruktury trakcyjnej. Roczne koszty eksploatacyjne związane $z$ obsługą trasy przez s.z.t. wynoszą 505 tys. zł. Ostatnim z kryteriów analizy jest koszt inwestycji związany $z$ danym wariantem obsługi trasy. W ramach tego kryterium wyróżnia się koszty wspólne inwestycji wynoszące $6,6 \mathrm{mln}$ zł. Koszty te związane są z budową nowych mijanek na linii 213 Reda - Hel mających na celu zwiększenie przepustowości linii, niezbędnej w sezonie letnim. Najniższymi kosztami inwestycji cechuje się obsługa trasy przy zastosowaniu s.z.t. 
for which these costs amount to PLN 425.8 thousand. Electric multiple units, on the other hand, are the most expensive to operate. The annual cost of their operation is PLN 1.1 million, which is mainly related to the cost of maintaining the traction infrastructure. Annual operating costs related to the route operation by DMU are 505 thousand PLN. The last criterion of the analysis is the investment cost related to a given route service option. This criterion includes common investment costs amounting to PLN 6.6 million. These costs are related to the construction of new passing passes on the 213 Reda - Hel line, aimed at increasing the line capacity, necessary in the summer season. The lowest investment costs are characteristic of the route service with the use of DMU. Assuming no rolling stock replacement, these costs are equal to the common investment costs. The highest investment costs are related to the operation of the route by EMU, which is associated with the electrification of line 213. These costs amount to PLN 185.7 million. The investment costs resulting from the use of reservoir teams to operate the traction route amount to PLN 141.2 million.

A multi-criteria comparative analysis was carried out for 4 different scenarios: environmental, operational, investment and the equal weight scenario. The weights of individual criteria, depending on the selected analysis scenario, are different. The use of storage units is the best variant according to the environmental and operational scenarios and the equal weights scenario. Route service using IPEMU is not the best variant according to the investment scenario, according to which the use of diesel multiple units is the best variant for the route service. This is due to the lack of the need to invest in diesel rolling stock, which is currently used on the route in question. The second reason for the superiority of DMU over IPEMU in the investment scenario includes the high price of the railroad multiple unit. As part of the analysis, it was proposed to operate the route using the Flirt electric multiple unit from Stadler, equipped with a hybrid on-board energy storage. The cost of such a vehicle is less than PLN 31 million. The cost of equipping it with an on-board energy storage is PLN 7.6 million. Therefore, the total purchase cost of the container multiple unit is PLN 38.6 million. A significant part of the cost of the on-board energy storage is the purchase cost of supercapacitors, the price of which is PLN 3.7 million. Reduction of the purchase cost of IPEMU is possible by resigning from equipping the vehicle with supercapacitors.

The technology of production of traction batteries is constantly being improved, which makes it possible to power storage trains without limiting the dynamics of the vehicle resulting from the limitation of charging and discharging currents of the
Koszty te przy założeniu braku wymiany tabory kolejowego równe są wspólnym kosztom inwestycji. Najwyższe koszty inwestycji związane są z obsługą trasy przez e.z.t., co wiąże się z elektryfikacją linii 213 . Koszty te wynoszą $185,7 \mathrm{mln}$ zł. Koszty inwestycyjne wynikające $\mathrm{z}$ zastosowania do obsługi trasy zasobnikowych zespołów trakcyjnych wynoszą 141,2 mln zł.

Wielokryterialną analizę porównawczą przeprowadzono dla 4 różnych scenariuszy: środowiskowego, eksploatacyjnego, inwestycyjnego oraz scenariusza równych wag. Wagi poszczególnych kryteriów w zależności od wybranego scenariusza analizy są różne. Zastosowanie zasobnikowych zespołów trakcyjnych jest najlepszym wariantem według scenariusza środowiskowego, eksploatacyjnego oraz scenariusza równych wag. Obsługa trasy przy wykorzystaniu z.e.z.t. nie jest najlepszym wariantem według scenariusza inwestycyjnego, według którego najlepszym wariantem obsługi trasy jest zastosowanie spalinowych zespołów trakcyjnych. Związane jest to brakiem konieczności inwestowania w spalinowy tabor kolejowy, który aktualnie jest stosowany na omawianej trasie. Drugą z przyczyn wyższości s.z.t. nad z.e.z.t. w ramach scenariusza inwestycyjnego jest wysoka cena zasobnikowego zespołu trakcyjnego. W ramach analizy zaproponowano obsługę trasy przy wykorzystaniu elektrycznego zespołu trakcyjnego Flirt f-my Stadler wyposażonego w hybrydowy pokładowy zasobnik energii. Koszt takiego pojazdu wynosi niespełna $31 \mathrm{mln}$ zł. Koszt wyposażenia go w pokładowy zasobnik energii to 7,6 mln zł. Łaczny koszt zakupu zasobnikowego zespołu trakcyjnego wynosi zatem 38,6 mln zł. Znaczną część kosztu pokładowego zasobnika energii stanowi koszt zakupu superkondensatorów, których cena wynosi 3,7 mln zł. Redukcja kosztu zakupu z.e.z.t. możliwa jest poprzez rezygnację $\mathrm{z}$ wyposażenia pojazdu $\mathrm{W}$ superkondensatory.

Technologia produkcji akumulatorów trakcyjnych nieustanie jest doskonalona, co daje możliwość zasilania zasobnikowych zespołów trakcyjnych bez ograniczania dynamiki pojazdu wynikającej z ograniczeń prądów ładowania oraz rozładowania akumulatora trakcyjnego. Przykładem obecnie produkowanego zasobnikowego zespołu trakcyjnego wyposażonego wyłącznie $\mathrm{w}$ baterię akumulatorów jest Talent 3 f-my Bombardier. Pojazd ten umożliwia przejechanie $40 \mathrm{~km}$ przy zasilaniu bateryjnym, a jego koszt wynosi $27 \mathrm{mln}$ zł. Zastosowanie takich pojazdów na analizowanej trasie, przy założeniu zakupu 3 zespołów pozwoliłoby na zredukowanie kosztów zakupu taboru zasobnikowego o $34,8 \mathrm{mln}$ zł. Przyjmując do analizy w ramach scenariusza inwestycyjnego konieczność wymiany taboru spalinowego oraz obsługe trasy przez seryjnie produkowane zespoły zasobnikowe powoduje, iż różnica kosztów inwestycyjnych obu rozwiązań zostaje zredukowana ze 134,6 
traction battery. The Bombardier Talent 3 is an example of a currently produced storage unit equipped only with a batteries. This vehicle allows you to travel $40 \mathrm{~km}$ with battery power, and its cost is PLN 27 million. The use of such vehicles on the analyzed route, assuming the purchase of 3 units, would allow for the reduction of the purchase costs of the rolling stock by PLN 34.8 million. Assuming the necessity to replace the diesel rolling stock and the route service by mass-produced storage units for the analysis as part of the investment scenario, the difference in investment costs of both solutions is reduced from PLN 134.6 million to PLN 35.0 million.

The multi-criteria analysis was carried out on the basis of the summer timetable data for regional trains on the Gdynia Główna - Hel route. As part of the further analysis of the use of storage units on this route, it is proposed to take into account the seasonal traffic of long-distance trains. These trains are currently run on the route in question by diesel locomotives. During the tourist season, an average of 6 arrivals and departures of long-distance trains is registered every day at the Hel station. It is predicted that taking into account the seasonal traffic of longdistance trains in the analysis will increase the advantage of route service by electric and storage units, with the advantage of IPEMU over EMU not changing under the environmental scenario.

As a result of the multi-criteria analysis, it can be concluded that the most advantageous variant of route service is the use of storage multiple units. This solution, in relation to the other variants, is characterized by the lowest harmfulness to the natural environment, the lowest operating costs and investment costs constituting $57 \%$ of the investment costs of route maintenance by electric multiple units.

List of major symbols and abbreviations

IPEMU - Independently Powered Electric Multiple-

Unit,

EMU - Electric Multiple-Unit,

DMU - Diesel Multiple-Unit,

SR - environmental criterion,

EE - operational economic criterion,

EI - economic investment criterion,

$\mathrm{SR}_{\mathrm{SC}}$ - environmental scenario,

$\mathrm{EE}_{\mathrm{SC}}$ - operational economic scenario,

EI $_{\mathrm{SC}}-$ economic investment scenario. mln zł do 35,0 mln zł.

Przeprowadzoną analizę wielokryterialną przeprowadzono w oparciu o dane letniego rozkładu jazdy pociągów regionalnych na trasie Gdynia Główna - Hel. W ramach dalszej analizy zastosowania zasobnikowych zespołów trakcyjnych na tej trasie proponuje się uwzględnienie sezonowego ruchu pociagów dalekobieżnych. Pociagi te aktualnie prowadzone są na omawianej trasie przez lokomotywy spalinowe. W sezonie turystycznym każdego dnia na stacji Hel rejestruje się średnio 6 przyjazdów oraz odjazdów pociągów dalekobieżnych. Przewiduje się, iż uwzględnienie w analizie sezonowego ruchu pociagów dalekobieżnych spowoduje zwiększenie przewagi obsługi trasy przez zespoły elektryczne oraz zasobnikowe, przy czym przewaga z.e.z.t. nad e.z.t. $\mathrm{w}$ ramach scenariusza środowiskowego nie ulegnie zmianie.

W wyniku przeprowadzonej analizy wielokryterialnej można stwierdzić, że najkorzystniejszym wariantem obsługi trasy jest wykorzystanie zasobnikowych zespołów trakcyjnych IPe.z.t. Rozwiązanie to w odniesieniu do pozostałych wariantów charakteryzują się najmniejszą szkodliwością dla środowiska naturalnego, najniższymi kosztami eksploatacji oraz kosztami inwestycyjnymi stanowiącymi 57\% kosztów inwestycyjnych obsługi trasy przez elektryczne zespoły trakcyjne e.z.t.

Wykaz ważniejszych oznaczeń i skrótów:

z.e.z.t. - autonomiczny elektryczny zespół trakcyjny (ang. Independently Powered Electric Multiple-Unit),

e.z.t. - elektryczny zespół trakcyjny (ang. Electric Multiple-Unit),

s.z.t. $\quad$ - spalinowy zespół trakcyjny (ang. Diesel Multiple-Unit),

SR - kryterium środowiskowe,

EE - kryterium ekonomiczne eksploatacyjne,

EI - kryterium ekonomiczne inwestycyjne,

$\mathrm{SR}_{\mathrm{SC}}$ - scenariusz środowiskowy,

$\mathrm{EE}_{\mathrm{SC}}$ - scenariusz ekonomiczny eksploatacyjny,

$\mathrm{EI}_{\mathrm{SC}}$ - scenariusz ekonomiczny inwestycyjny.

\section{BIBLIOGRAPHY/BIBLIOGRAFIA}

[1] rozladowani.pl, Nawet w Polsce samochód elektryczny emituje mniej CO2 niż pojazdy spalinowe, https://rozladowani.pl/lepsze-od-spalinowych/, (data dostęu 18.08 .2020 r.)

[2] lotos.pl, Ceny hurtowe paliw https://www.lotos.pl/144/poznaj_lotos /dla_biznesu/hurtowe_ceny_paliw (data dostęu 04.08.2020 r.)

[3] trójmiasto.pl, Szynobusy na linii PKM zużywaja więcej paliwa niż zakładano, https://www.trojmiasto.pl/ wiadomosci/Szynobusy-na-linii-PKM-zuzywaja-wiecej-paliwa-niz-zakladano-n94452.html, (data dostępu 03.08.2020 r.) 
[4] motohurtownia.com, Dane katalogowe Lokomotiv Extra CF 40, https://www.moto hurtownia.com/ productpol-3578-Lokomotiv-Extra-CF-40.html (data dostępu 03.08.2020 r.)

[5] Szkoda M., Koszt cyklu trwałości jako kryterium efektywności modernizacji lokomotyw spalinowych, Politechnika Krakowska, Kraków 2007 r.

[6] slovnaft.pl, Większa niezawodność https://slovnaft.pl/pl/oleje-i-smary/transport/historie-sukcesu/wiekszaniezawodnosc-transport/ (data dostępu 04.08.2020 r.)

[7] forsal.pl, Ile zapłacimy za prad? Ceny hurtowe energii szacuje się na 240-280 zt za MWh do 2022 r., https://forsal.pl/artykuly/1440311,ile-zaplacimy-za-prad-ceny-hurtowe-energii-szacuje-sie-na-240-280-zlza-mwh-do-2022-r.html, (data dostęu 04.08.2020 r.)

[8] Bistyp Koleje i tramwaje, Katalog cen robót kolejowych i tramwajowych, Wydawnictwo Wolters Kluwer Polska Sp. z o.o. Warszawa, II kwartat 2020 r.

[9] Gala-de Vacqueret M., Kaczmarski P., Mitelski K.,Plińska M., Ptaneta M., Sierakowski T., Sikorska-Ożgo M., Wypych A., Biuletyn cen obiektów budowlanych, cz. II Obiekty inżynieryjne. Sekocenbud, zeszyt 33/2020 (1951), Ośrodek wdrożeń ekonomiczno-organizacyjnych budownictwa Promocja Sp. z o.o. Warszawa, II kwartat $2020 \mathrm{r}$.

[10]Milana Kosijer, Miloš Ivić, Milan Marković, Ivan Belošević, Multicriteria decision-making in railway route planning and design, GRADEVINAR 64 (2012) 3, 195-205, Belgrad 2012 r.

[11]Karkosiński D., Stromski P., Karkosińska-Brzozowska N., Hybrydowy zasobnik energii dla elektrycznych zespołów trakcyjnych do obstugi częściowo zelektryfikowanej linii Gdynia - Hel , Pojazdy szynowe nr 1/2021, 